ISSN 1678-3921

Journal homepage: www.embrapa.br/pab

For manuscript submission and journal contents, access: www.scielo.br/pab

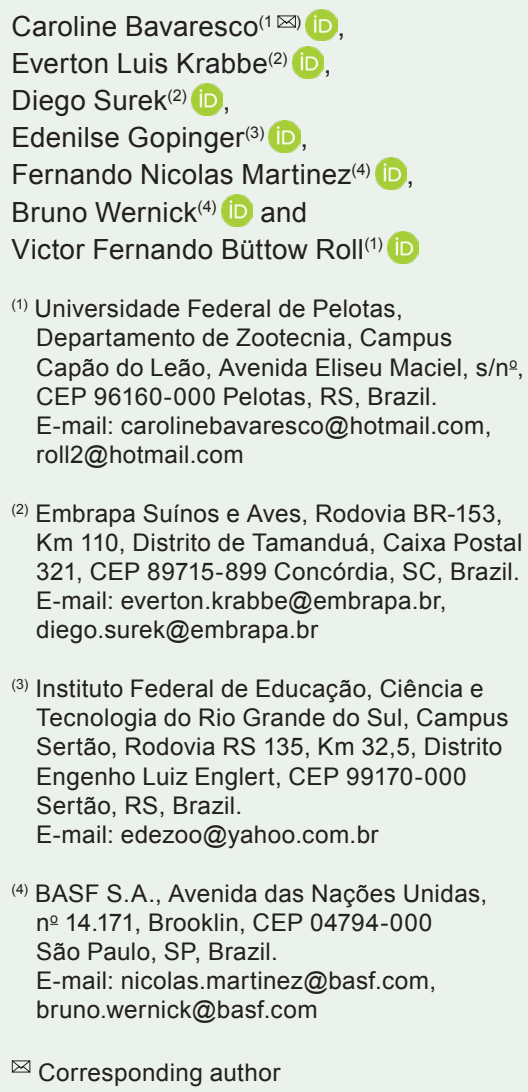

(2) Embrapa Suínos e Aves, Rodovia BR-153, $\mathrm{Km}$ 110, Distrito de Tamanduá, Caixa Postal 321, CEP 89715-899 Concórdia, SC, Brazil. E-mail: everton.krabbe@embrapa.br, diego.surek@embrapa.br

(3) Instituto Federal de Educação, Ciência e Tecnologia do Rio Grande do Sul, Campus Sertão, Rodovia RS 135, Km 32,5, Distrito Engenho Luiz Englert, CEP 99170-000 Sertão, RS, Brazil.

E-mail: edezoo@yahoo.com.br

(4) BASF S.A., Avenida das Nações Unidas, no 14.171, Brooklin, CEP 04794-000 São Paulo, SP, Brazil. E-mail: nicolas.martinez@basf.com, bruno.wernick@basf.com

$\bowtie$ Corresponding author

Received

October 09, 2019

Accepted

July 22, 2021

How to cite BAVARESCO, C.; KRABBE, E.L.; SUREK, D. GOPINGER, E.; MARTINEZ, F.N.; WERNICK B.; ROLL, V.F.B. Dietary hybrid phytase and carbohydrases on nutrient digestibility and bone quality of broiler chickens. Pesquisa Agropecuária Brasileira, v.56, e01668, 2021. DOI: https://doi.org/10.1590/S1678-3921. pab2021.v56.01668.

\section{Dietary hybrid phytase and carbohydrases on nutrient digestibility and bone quality of broiler chickens}

\begin{abstract}
The objective of this work was to evaluate the effect of the use of hybrid phytase, alone or combined with carbohydrases, in poultry diets with nutritional reductions of calcium, available phosphorus, and metabolizable energy on the nutrient digestibility and bone quality of broiler chickens. A total of 1,875 broilers were distributed in five treatments in a completely randomized design, with 15 replicates of 25 chickens each. The treatments consisted of a positive control feed (T1) and of four negative controls (T2 to T5): T1, basal diet (BD) with corn and soybean; T2 and T3, BDs with reductions of 70 and $100 \mathrm{kcal} \mathrm{kg}^{-1}$ metabolizable energy, respectively, and both with reductions of $0.16 \% \mathrm{Ca}$ and $0.15 \%$ available $\mathrm{P}$; and T4 and T5, BDs with the same nutritional reductions, but supplemented with enzymes, i.e., $\mathrm{T} 4=\mathrm{T} 2+500$ phytase units (FTU) per kilogram and T5 $=\mathrm{T} 3+500 \mathrm{FTU} \mathrm{kg}^{-1}$ +560 xylanase units (TXU) per kilogram +250 glucanase units (TGU) per kilogram. The use of $500 \mathrm{FTU} \mathrm{kg}^{-1}$ hybrid phytase in pelleted corn-soybean meal diets allows a good digestive performance by broilers and replaces the nitrogen-corrected apparent metabolizable energy at $70 \mathrm{kcal} \mathrm{kg}^{-1}$, as well as $0.16 \% \mathrm{Ca}$ and $0.15 \%$ available $\mathrm{P}$.
\end{abstract}

Index terms: calcium, energy, enzymes, phosphorus, zinc.

\section{Fitase híbrida e carboidrases dietéticas sobre digestibilidade de nutrientes $e$ qualidade de ossos em frangos de corte}

Resumo - O objetivo deste trabalho foi avaliar a eficiência do uso de fitase híbrida, associada ou não com carboidrases, em dietas para frangos, com reduções nutricionais de cálcio, fósforo disponível e energia metabolizável, sobre a digestibilidade dos nutrientes e a qualidade óssea em frangos de corte. Um total de 1.875 frangos foi distribuído em cinco tratamentos, em delineamento inteiramente casualizado, com 15 repetições de 25 frangos cada uma. Os tratamentos consistiram de uma dieta controle positivo (T1) e de quatro controles negativos (T2 a T5): T1, dieta basal (DB) de milho e farelo de soja; T2 e T3, DBs com reduções de 70 e $100 \mathrm{kcal} \mathrm{kg}^{-1}$ de energia metabolizável, respectivamente, e ambas com reduções de $0,16 \%$ de $\mathrm{Ca}$ e $0,15 \%$ de fósforo disponível; e T4 e T5, DBs com as mesmas reduções nutricionais, mas com a adição de enzimas, ou seja, T4 $=\mathrm{T} 2+500$ unidades de fitase (FTU) por quilograma e $\mathrm{T} 5=\mathrm{T} 3+500 \mathrm{FTU} \mathrm{kg}^{-1}+560$ unidades de xilanase (TXU) por quilograma +250 unidades de glucanase (TGU) por quilograma. $\mathrm{O}$ uso de $500 \mathrm{FTU} \mathrm{kg}^{-1}$ de fitase híbrida em rações peletizadas com milho e farelo de soja permite bom desempenho digestivo por frangos de corte e substitui a energia metabolizável aparente corrigida por nitrogênio a $70 \mathrm{kcal} \mathrm{kg}^{-1}$, bem como $0,16 \%$ de $\mathrm{Ca}$ e $0,15 \%$ de $\mathrm{P}$ disponível.

Termos para indexação: cálcio, energia, enzimas, fósforo, zinco. 


\section{Introduction}

Enzymes have been added over 20 years to poultry feed for different purposes (Choct, 2006). One of the main ones is to increase nutrient digestibility, which is highly advantageous because it allows reducing the inclusion of expensive ingredients in the composition of the feed, reducing its cost without compromising animal performance (Romero et al., 2014). In addition, dietary enzyme supplementation is important to reduce the amount of certain nutrients to limits specific for a sustainable production (Ravindran, 2014).

Among the known enzymes, phytase has been mainly used to cleave phytate-releasing phosphorous for absorption (Dersjant-Li et al., 2015). However, while releasing $\mathrm{P}$, other nutrients - such as calcium, manganese, magnesium, iron, and zinc (Nissar et al., 2017), as well as proteins and carbohydrates (Slominski, 2011) - can also be released and absorbed. Therefore, when using phytase, not only $\mathrm{P}$ should be considered but all other nutrients, previously chelated by phytic acid (Woyengo \& Nyachoti, 2011).

Additionally, exogenous enzymes can act synergistically, increasing nutrient bioavailability and animal performance (Woyengo \& Nyachoti, 2011). These enzymes include the carbohydrases group that can hydrolyze non-starch polysaccharides, as shown by Yu \& Chung (2004) and Meng \& Slominski (2005), who reported that supplementing corn and soybean meal-based poultry diets with xylanase and $\beta$-glucanase increased metabolizable energy content. Carbohydrases can also promote an increase in phytase efficacy in degrading phytate (Woyengo \& Nyachoti, 2011), leveraging phytase action.

The enzyme industry, as many others, has introduced novel products with an increased efficacy, stability during feed processing, and resistance to the adverse conditions of the bird gastrointestinal tract (Ravindran, 2013). Hybrid bacterial phytases, for example, have been reported to improve the digestibility of $\mathrm{P}$, as well as of other nutrients linked to phytate (Torrallardona et al., 2017). However, although enzymes can act synergically, it is still not clear if this potential can be achieved by combining enzymes from different generations.

The objective of this work was to evaluate the effect of the use of hybrid phytase, alone or combined with carbohydrases, in poultry diets with nutritional reductions of calcium, available phosphorus, and metabolizable energy on the nutrient digestibility and bone quality of broiler chickens.

\section{Materials and Methods}

The experiment was conducted at the experimental poultry sector of Embrapa Suínos e Aves, located in the municipality of Concórdia, in the state of Santa Catarina, Brazil. The project was approved by the ethics committee for animal use of Embrapa, under number 006-2017. The experimental period lasted 28 days.

A total of 1,875 Cobb 500 male broilers, with 28 days of age, were housed in $1.65 \times 1.70 \mathrm{~m}$ floor pens equipped with tubular feeders and five nipple drinkers per pen. Poultry house temperature was controlled by a central heating system and ventilators. Bedding consisted of pine wood shavings. The birds had an initial body weight of $46.9 \pm 3.7 \mathrm{~g}$ and were distributed in a completely randomized design among five treatment groups, with 15 replicates of 25 birds each.

The experimental diets included a positive control (T1) and four negative controls (T2 to T5): T1, basal diet (BD) with corn and soybean, which met the typical nutritional requirements (Rostagno, 2011); T2 and T3, BDs with reductions of 70 and $100 \mathrm{kcal} \mathrm{kg}^{-1}$, respectively, and both with reductions of $0.16 \% \mathrm{Ca}$ and $0.15 \%$ available $\mathrm{P}$; and $\mathrm{T} 4$ and $\mathrm{T} 5$, BDs with the same nutritional reductions but supplemented with enzymes, i.e., $\mathrm{T} 4=\mathrm{T} 2+500$ phytase units (FTU) per kilogram and $\mathrm{T} 5=\mathrm{T} 3+500 \mathrm{FTU} \mathrm{kg}^{-1}+560$ xylanase units (TXU) per kilogram +250 glucanase units (TGU) per kilogram (Table 1).

The used hybrid phytase was Natuphos E 10000 G (BASF, Ludwigshafen, Germany), which is granulated and a microbially derived myo-inositolhexakisphosphate beta-phosphohydrolase (EC 3.1.3.26), exhibiting a phytase activity of 10,000 FTU $\mathrm{g}^{-1}$. FTU is defined as the amount of enzymes that releases $1.0 \mu \mathrm{mol}$ per minute of inorganic $\mathrm{P}$, in the form of $0.0051 \mathrm{~mol} \mathrm{~L}^{-1}$ sodium phytate, at $\mathrm{pH} 5.5$ and $37^{\circ} \mathrm{C}$ (Basf, 2017). According to the manufacturer, that molecule was created by hybridization with three bacteria, which confers it a higher resistance to acidic conditions, endogenous proteases, and pelleting temperatures up to $95^{\circ} \mathrm{C}$.

The carbohydrase used was Natugrain TS (BASF, Ludwigshafen, Germany), cleaving bonds commonly 
targeted by endo-1,4-beta-xylanase (EC 3.2.1.8) and endo-1,4-beta-glucanase (EC 3.2.1.4). This product is produced from Aspergillus niger. According to the manufacturer, TXU is defined as the amount of enzymes that releases $5.0 \mu \mathrm{mol}$ per minute of reducing sugars, measured as equivalent xylase, from a 0.01 $\mathrm{g} \mathrm{mL} \mathrm{m}^{-1}$ solution of arabinoxylan at $\mathrm{pH} 3.5$ and $40^{\circ} \mathrm{C}$. Similarly, TGU is defined as the amount of enzymes that releases $1.0 \mu \mathrm{mol}$ per minute of reducing sugars, measured as equivalent glucose, from a $0.00714 \mathrm{~g} \mathrm{~mL}^{-1}$ solution of beta-glucan, at $\mathrm{pH} 3.5$ and $40^{\circ} \mathrm{C}$.

The feeding program consisted of three phases: prestarter, from 1-7 days; starter, 8-21 days; and grower, 22-28 days. The feed was pelleted at $80^{\circ} \mathrm{C}$ for $20 \mathrm{~s}$ and its consumption was ad libitum. Feed composition and the nutritional profiles of the experimental diets are presented in Table 2.

The enzymatic activity (expressed per kilogram of feed) of each diet was evaluated by Laboratório CBO (Valinhos, São Paulo, SP, Brazil). In T4, recovery was measured considering the following values in each phase: 420 FTU in pre-starter, 440 FTU in starter, and 510 FTU in grower. In T5, these values were: 440 FTU, 529 TXU, and 322 TGU in pre-starter; 480 FTU, 579 TXU, and 290 TGU in starter; and 470 FTU, 540 TXU, and 321 TGU in grower.

For bone quality measurements, three birds from each experimental unit (average body weight $\pm 5 \%$ of the pen mean) were slaughtered at 28 days of age for ileal content and tibia collection.

Nutrient digestibility was determined using the ileal sampling method, by adding $0.5 \%$ chromium (III) oxide $\left(\mathrm{Cr}_{2} \mathrm{O}_{3}\right)$ to all experimental diets as an undigestible indicator during 7 days (from the twenty- first to the twenty-eighth day). Immediately after slaughter, the ileum of each animal was exposed by abdominal incision: a $20 \mathrm{~cm}$ segment, ending $4 \mathrm{~cm}$ before the ileocecal junction was removed, and the contents of the segments were collected, weighed, and frozen for further analysis. Later, the frozen contents were lyophilized (freeze-dried at $-50^{\circ} \mathrm{C}$ and $-80 \mathrm{kPa}$ for 72 hours), weighed, and homogenized, being ground with the A11 Basic analytical mill (IKA, Staufen, Germany) and analyzed at the Physicochemical Laboratory of Embrapa, located in Concórdia, in the state of Santa Catarina, Brazil.

Samples of the experimental feeds were also assessed at the same laboratory, in order to determine: dry matter (DM), by method 012/IV of Instituto Adolfo Lutz (Zenebon et al., 2008), using the SX12DTME drying oven (Prolab, São Paulo, SP, Brazil); mineral matter (MM), by method 36 of Compêndio Brasileiro de Alimentação Animal (2009), using the SSFM67L muffle furnace (Prolab, São Paulo, SP, Brazil); Ca, with the NovAA 800 flame atomic absorption spectrometer (AnalytikJena $\mathrm{GmbH}$, Überlingen, Germany); P, by method 958.01 of Association of Official Analytical Chemists (Latimer, 2012); crude protein (CP), using the FP 628 Dumas protein analyzer (LECO, St. Joseph, MI, USA); and gross energy, with the AC500 automatic calorimeter (LECO, St. Joseph, MI, USA).

In addition, $\mathrm{Cr}_{2} \mathrm{O}_{3}$ was measured using inductively coupled plasma optical emission spectrometry, and indigestibility factor (IF) values were calculated for each sample, as follows:

$(\mathrm{IF})=$ Marker in the feed $(\% \mathrm{DM}) /$ Marker in ileal content $(\% \mathrm{DM})$

Table 1. Experimental diets (treatments) fed to Cobb 500 male broiler chickens.

\begin{tabular}{|c|c|c|c|c|c|}
\hline \multirow[t]{2}{*}{ Nutritional reduction } & \multicolumn{5}{|c|}{ Treatment } \\
\hline & T1 & $\mathrm{T} 2$ & $\mathrm{~T} 3$ & T4 & T5 \\
\hline Energy $\left(\mathrm{kcal} \mathrm{kg}^{-1}\right)$ & & 70 & 100 & 70 & 100 \\
\hline Calcium (\%) & $\mathrm{PC}^{(1)}$ & 0.16 & 0.16 & 0.16 & 0.16 \\
\hline \multirow[t]{2}{*}{ Available phosphorous (\%) } & & 0.15 & 0.15 & 0.15 & 0.15 \\
\hline & \multicolumn{5}{|c|}{ Enzyme supplementation } \\
\hline Phytase (FTU kg-1) & 0 & 0 & 0 & 500 & 500 \\
\hline Xylanase $\left(\mathrm{TXU} \mathrm{kg}^{-1}\right)$ & 0 & 0 & 0 & 0 & 560 \\
\hline Glucanase (TGU kg-1) & 0 & 0 & 0 & 0 & 250 \\
\hline
\end{tabular}

(1)Positive control. Values according to the recommendations of the Brazilian tables for poultry and swine (Rostagno, 2011) for the regular performance of male broilers, in three growing phases: pre-starter (1-7 days), 2,925 kcal kg-1, $0.92 \% \mathrm{Ca}$, and $0.47 \%$ available P; starter (8-21 days), 2,980 kcal kg-1, $0.86 \% \mathrm{Ca}$, and $0.38 \%$ available $\mathrm{P}$; and grower (22-28 days), $3,050 \mathrm{kcal} \mathrm{kg}^{-1}, 0.75 \% \mathrm{Ca}$, and $0.33 \%$ available $\mathrm{P}$. 
Using the analytical results, digestibility coefficients (DC) were obtained for DM, MM, Ca, P, CP, and nitrogen-corrected apparent metabolizable energy (AMEn), as described by Sakomura \& Rostagno (2007):

$\mathrm{DC}(\%)=100-[\mathrm{IF} \times($ excreted nutrient $/$ nutrient in the feed) $\times 100$ ]

\section{$\operatorname{AMEn}\left(\mathrm{kcal} \mathrm{kg}^{-1} \mathrm{DM}\right)=\mathrm{FGE}-[(\mathrm{DGE} \times \mathrm{IF})+$ $8.22 \times \mathrm{NB}]$}

where $\mathrm{NB}$ is $\mathrm{N}$ balance, representing $\mathrm{N}$ in the diet (excreted $\mathrm{N} \times \mathrm{IF}$ ); and FGE and DGE correspond to feed gross energy and digesta gross energy, respectively.

For the bone quality analysis, the right and left tibias were extracted from three selected animals from

Table 2. Composition and nutritional profiles of poultry experimental diets containing hybrid phytase and carbohydrases.

\begin{tabular}{|c|c|c|c|c|c|c|c|c|c|}
\hline \multirow[t]{2}{*}{ Ingredient (\%) } & \multicolumn{3}{|c|}{ Pre-starter (1-7 days) } & \multicolumn{3}{|c|}{ Starter (8-21 days) } & \multicolumn{3}{|c|}{ Grower (22-28 days) } \\
\hline & T1 & $\mathrm{T} 2 / \mathrm{T} 4$ & $\mathrm{~T} 3 / \mathrm{T} 5$ & T1 & $\mathrm{T} 2 / \mathrm{T} 4$ & T3/T5 & T1 & $\mathrm{T} 2 / \mathrm{T} 4$ & T3/T5 \\
\hline Corn & 48.440 & 48.440 & 48.440 & 52.380 & 52.380 & 52.380 & 50.727 & 50.727 & 50.727 \\
\hline Soybean meal ( $44 \%$ crude protein) & 44.050 & 44.050 & 44.050 & 40.570 & 40.570 & 40.570 & 40.660 & 40.650 & 40.650 \\
\hline Soybean oil & 3.240 & 2.450 & 2.105 & 3.385 & 2.565 & 2.236 & 4.456 & 3.663 & 3.321 \\
\hline Kaolin & 0.045 & 1.540 & 1.885 & 0.040 & 1.570 & 1.884 & 0.526 & 1.991 & 2.323 \\
\hline Chromic oxide & - & - & - & - & - & - & 0.526 & 0.526 & 0.526 \\
\hline Dicalcium phosphate $^{(1)}$ & 1.780 & 0.970 & 0.970 & 1.330 & 0.520 & 0.520 & 1.069 & 0.255 & 0.255 \\
\hline Limestone $^{(2)}$ & 0.970 & 1.070 & 1.070 & 1.120 & 1.220 & 1.220 & 1.010 & 1.112 & 1.112 \\
\hline Salt & 0.530 & 0.530 & 0.530 & 0.500 & 0.500 & 0.500 & 0.480 & 0.480 & 0.480 \\
\hline DL-methionine & 0.300 & 0.300 & 0.300 & 0.210 & 0.210 & 0.210 & 0.151 & 0.151 & 0.151 \\
\hline L-lysine & 0.170 & 0.170 & 0.170 & 0.060 & 0.060 & 0.060 & 0.000 & 0.000 & 0.000 \\
\hline Toxin binder ${ }^{(3)}$ & 0.185 & 0.185 & 0.185 & 0.185 & 0.185 & 0.185 & 0.185 & 0.185 & 0.185 \\
\hline L-threonine & 0.080 & 0.080 & 0.080 & 0.010 & 0.010 & 0.010 & 0.000 & 0.000 & 0.000 \\
\hline Vitamin premix ${ }^{(4)}$ & 0.100 & 0.100 & 0.100 & 0.100 & 0.100 & 0.100 & 0.100 & 0.100 & 0.100 \\
\hline Mineral premix ${ }^{(5)}$ & 0.050 & 0.050 & 0.050 & 0.050 & 0.050 & 0.050 & 0.050 & 0.050 & 0.050 \\
\hline Monensin sodium (Coban) & 0.050 & 0.050 & 0.050 & 0.050 & 0.050 & 0.050 & 0.050 & 0.050 & 0.050 \\
\hline Butylated hydroxytoluene & 0.010 & 0.010 & 0.010 & 0.010 & 0.010 & 0.010 & 0.010 & 0.010 & 0.010 \\
\hline 500 FTU kg $^{-1}$ phytase $^{(6)}$ & - & $\mathrm{T} 4$ & $\mathrm{~T} 5$ & - & $\mathrm{T} 4$ & $\mathrm{~T} 5$ & - & $\mathrm{T} 4$ & $\mathrm{~T} 5$ \\
\hline Xylanase + glucanase $^{(7)}$ & - & - & T5 & - & - & T5 & - & - & T5 \\
\hline \multirow[t]{2}{*}{ Total } & 100 & 100 & 100 & 100 & 100 & 100 & 100 & 100 & 100 \\
\hline & \multicolumn{9}{|c|}{ Nutritional profile (calculated) } \\
\hline $\operatorname{AMEn}\left(\mathrm{kcal} \mathrm{kg}^{-1}\right)$ & $2,925^{(8)}$ & 2,855 & 2,825 & $2,980^{(8)}$ & 2,910 & 2,880 & $3,050^{(8)}$ & 2,980 & 2,950 \\
\hline Crude protein $(\%)$ & 23.65 & 23.65 & 23.65 & 22.14 & 22.14 & 22.14 & 22.01 & 22.03 & 22.03 \\
\hline Fat $(\%)$ & 5.72 & 4.94 & 4.60 & 5.95 & 5.17 & 4.83 & 6.99 & 6.20 & 5.86 \\
\hline Crude fiber $(\%)$ & 3.17 & 3.17 & 3.17 & 3.05 & 3.05 & 3.05 & 3.05 & 3.05 & 3.05 \\
\hline Available phosphorous (\%) & $0.47^{(8)}$ & 0.32 & 0.32 & $0.38^{(8)}$ & 0.23 & 0.23 & $0.33^{(8)}$ & 0.18 & 0.18 \\
\hline Total phosphorous (\%) & 0.74 & 0.58 & 0.58 & 0.64 & 0.49 & 0.49 & 0.59 & 0.44 & 0.44 \\
\hline Calcium (\%) & $0.92^{(8)}$ & 0.76 & 0.76 & $0.86^{(8)}$ & 0.70 & 0.70 & $0.75^{(8)}$ & 0.59 & 0.59 \\
\hline Digestible lysine (\%) & 1.30 & 1.30 & 1.30 & 1.14 & 1.14 & 1.14 & 1.09 & $1.09 / 1.14$ & $1.09 / 1.14$ \\
\hline Digestible methionine cystine (\%) & 0.93 & 0.93 & 0.93 & 0.82 & 0.82 & 0.82 & 0.76 & $0.76 / 0.82$ & $0.76 / 0.82$ \\
\hline Digestible methionine (\%) & 0.59 & 0.59 & 0.59 & 0.49 & 0.49 & 0.49 & 0.43 & $0.43 / 0.49$ & $0.43 / 0.49$ \\
\hline Digestible threonine (\%) & 0.84 & 0.84 & 0.84 & 0.74 & 0.74 & 0.74 & 0.73 & $0.73 / 0.74$ & $0.73 / 0.74$ \\
\hline Digestible tryptophan (\%) & 0.26 & 0.26 & 0.26 & 0.24 & 0.24 & 0.24 & 0.25 & $0.25 / 0.24$ & $0.25 / 0.24$ \\
\hline
\end{tabular}

(1) Quantities: $210 \mathrm{~g} \mathrm{~kg}^{-1}$ minimum calcium, $250 \mathrm{~g} \mathrm{~kg}^{-1}$ maximum calcium, and $180 \mathrm{~g} \mathrm{~kg}^{-1}$ phosphorus. (2) $33 \%$ minimum quantity of calcium. ${ }^{\left({ }^{3}\right)} \mathrm{Mycotoxin}^{2}$ binder with aluminosilicates, yeast wall, and activated carbon. ${ }^{(4)}$ Composition of the product (guarantee levels per kilogram of product): 11,000,000 I.U. vitamin A, 4,000,000 I.U. vitamin D3, 55,000 I.U. vitamin E, 3,000 mg vitamin K3, 2,300 mg vitamin B1, 7,000 mg vitamin B2, $12 \mathrm{~g}$ pantothenic acid, 4,000 $\mathrm{mg}$ vitamin $\mathrm{B} 6,25,000 \mu \mathrm{g}$ vitamin B12, $60 \mathrm{~g}$ nicotinic acid, 2,000 $\mathrm{mg}$ folic acid, $250 \mathrm{mg}$ biotin, and $300 \mathrm{mg}$ selenium. ${ }^{(5)}$ Composition of the product (guarantee levels per kilogram of product): $100 \mathrm{~g}$ iron, $20 \mathrm{~g}$ copper, $130 \mathrm{~g}$ manganese, $130 \mathrm{~g}$ zinc, and 2,000 mg iodine. ${ }^{(6)} \mathrm{Natuphos} \mathrm{E} 10000 \mathrm{G}$ (BASF,

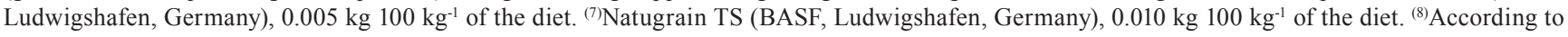
the recommendations of the Brazilian tables for poultry and swine (Rostagno, 2011) for the regular performance of male broilers. 
each experimental unit and tested for breaking force $(\mathrm{kgf})$, rigidity $\left(\mathrm{kgf} \mathrm{mm}^{-1}\right)$, and flexibility $\left(\mathrm{kg} \mathrm{s}^{-1}\right)$. Bone strength is typically measured as applied force per bone area. The ratio of force and distance (distance of probe movement until bone rupture) corresponds to bone rigidity (Świątkiewicz \& Arczewska-Wlosek, 2012), whereas bone flexibility is represented by area and is measured as bone deformity as a function of applied force (Gopinger et al., 2017). For the analysis, the TA.XTPlus texture analyzer (Texture Technologies Corporation, Hamilton, MA, USA) was used, being connected to the Exponent software (Stable Micro Systems, Surrey, United Kingdom).

After the physical analysis, the bones were dried at $105^{\circ} \mathrm{C}$ to measure DM (Zenebon et al., 2008). The tibias were then subjected to total ash analysis (Compêndio..., 2009). Once this was completed, the six tibias from each experimental unit were pooled and ground, stored in plastic bags, and subsequently analyzed for $\mathrm{Ca}$ content, using atomic absorption, and for $\mathrm{P}$ and $\mathrm{Zn}$ contents, using flow injection analysis, as described by method 965.17 of AOAC (Cunniff, 1995).

The data were subjected to the analysis of variance. After the least-squares means procedure, means were compared by Tukey's test. All analyses were performed using the R statistical software (R Core Team, 2015), at $5 \%$ probability.

\section{Results and Discussion}

The experimental diets presented significantly different AMEn contents than expected due to the strategy used for their formulation, in which a nutritional matrix for enzymes was adopted (Table 3). The diets that were not supplemented with enzymes (T2 and T3) yielded lower AMEn values of 3,203 and 3,192 $\mathrm{kcal} \mathrm{kg}^{-1}$, respectively, when compared with that of $3,368 \mathrm{kcal} \mathrm{kg}^{-1}$ of the positive control (T1). However, the diets supplemented with enzymes (T4 and T5) showed a recovered AMEn, with an average of 3,273 and 3,216 kcal kg-1, respectively, representing an increase of 2.16 and $0.76 \%$ for T4 versus T2 and for $\mathrm{T} 5$ versus $\mathrm{T} 3$, indicating improved energy availability as a consequence of enzyme supplementation.

The hybrid phytase was able to replace the applied energy reduction of $70 \mathrm{kcal} \mathrm{kg}^{-1} \mathrm{DM}$, indicating that phytase acts not only on the provision of $\mathrm{P}$ but also on that of other nutrients, which can be metabolized as energy by birds. Phytase, associated with carbohydrases, also increased AMEn in $24 \mathrm{kcal} \mathrm{kg}^{-1}$ $\mathrm{DM}$; however, the energy reduction in these diets was greater, being of $100 \mathrm{kcal} \mathrm{kg}^{-1} \mathrm{DM}$. In the diets supplemented with enzymes, the reduced AMEn level was restored to one statistically equivalent to that of the positive control.

When consolidating data of 17 studies on different diets - most made of wheat and sorghum and a few of corn and soybean, with an average phytase inclusion rate of 662 units per kilogram (range from 400 to 1,200 units) -, Lei et al. (2013) observed that the amino acid response in poultry fed with enzymes was inconsistent and the energy response was less than $100 \mathrm{kcal} \mathrm{kg}^{-1}$ of $\operatorname{diet}\left(0.36 \mathrm{MJ} \mathrm{kg}^{-1}\right)$.

For the efficacy of enzymes during their supplementation, it should be taken into account that

Table 3. Values of nitrogen-corrected apparent metabolizable energy $\left(\mathrm{AME}_{\mathrm{n}}\right)$ on a dry matter basis and of ileal digestibility coefficients of crude protein (CP), dry matter (DM), mineral matter (MM), calcium, and phosphorus in broilers fed diets containing a hybrid phytase associated with carbohydrases (mean \pm standard deviation) ${ }^{(1)}$.

\begin{tabular}{lcccccc}
\hline Treatment ${ }^{(2)}$ & \multirow{2}{*}{$\begin{array}{c}\text { AMEn } \\
\left(\mathrm{kcal} \mathrm{kg}^{-1} \mathrm{DM}\right)\end{array}$} & \multicolumn{5}{c}{ Ileal digestibility coefficients on a dry matter basis (\%) } \\
\cline { 3 - 6 } & $3,368.40 \pm 100.42 \mathrm{a}$ & $85.02 \pm 1.65 \mathrm{a}$ & $71.21 \pm 1.96 \mathrm{a}$ & $41.20 \pm 3.18 \mathrm{a}$ & $41.88 \pm 15.81$ & $55.45 \pm 6.80 \mathrm{c}$ \\
$\mathrm{T} 1$ & $3,203.36 \pm 129.61 \mathrm{~b}$ & $81.79 \pm 2.23 \mathrm{~b}$ & $64.72 \pm 2.80 \mathrm{c}$ & $31.55 \pm 1.91 \mathrm{c}$ & $41.52 \pm 10.16$ & $58.93 \pm 10.08 \mathrm{c}$ \\
$\mathrm{T} 2$ & $3,192.17 \pm 183.38 \mathrm{~b}$ & $81.63 \pm 2.93 \mathrm{~b}$ & $66.16 \pm 2.21 \mathrm{bc}$ & $33.11 \pm 2.98 \mathrm{c}$ & $49.96 \pm 13.56$ & $62.05 \pm 9.10 \mathrm{bc}$ \\
$\mathrm{T} 3$ & $3,273.77 \pm 164.03 \mathrm{ab}$ & $83.71 \pm 2.82 \mathrm{ab}$ & $68.21 \pm 2.55 \mathrm{~b}$ & $37.73 \pm 2.72 \mathrm{~b}$ & $48.72 \pm 9.30$ & $70.10 \pm 8.49 \mathrm{ab}$ \\
T4 & $3,216.62 \pm 161.65 \mathrm{ab}$ & $83.12 \pm 2.78 \mathrm{ab}$ & $65.74 \pm 3.83 \mathrm{bc}$ & $37.13 \pm 4.52 \mathrm{~b}$ & $51.59 \pm 10.30$ & $72.48 \pm 11.36 \mathrm{a}$ \\
T5 & 0.01 & $<0.0001$ & $<0.0001$ & $<0.0001$ & 0.07 & $<0.0001$ \\
\hline Probability & & &
\end{tabular}

${ }^{(1)}$ Means followed by equal letters, in the columns, do not differ from each other by Tukey's test, at 5\% probability. ${ }^{(2)} \mathrm{T} 1$, positive control basal diet (BD) with corn and soybean meal; T2, BD with reduction of $70 \mathrm{kcal} \mathrm{kg}^{-1}, 0.16 \% \mathrm{Ca}$, and $0.15 \%$ available $\mathrm{P}$; T3, BD with reduction of $100 \mathrm{kcal}^{\mathrm{kg}}{ }^{-1}, 0.16 \% \mathrm{Ca}$, and $0.15 \%$ available P; T4, T2 +500 phytase units (FTU) per kilogram; and T5, T3 $+500 \mathrm{FTU} \mathrm{kg}^{-1}+560$ xylanase units per kilogram +250 glucanase units per kilogram. 
corn-soybean meal-based diets contain a lower amount of non-starch polysaccharides such as arabinoxylans and $\beta$-glucans (Stefanello et al., 2016; Slominski, 2011). This is important since the presence of a substrate affects enzyme action, with more expressive results expected when carbohydrates are supplemented in diets with a greater amount of substrate, such as those containing wheat, rye, and barley (Zarghi, 2018). The results of the present study are indicative of the positive action of the use of carbohydrases in association with hybrid phytase in diets based on corn and soybean meal, which allowed a reduction of $100 \mathrm{kcal} \mathrm{kg}^{-1}$ in diet composition, representing an extra contribution of $30 \mathrm{kcal} \mathrm{kg}^{-1}$ AMEn. This confirms a previous study conducted with broiler chickens by Krabbe et al. (2014), who tested the Naturgrain TS enzyme package containing xylanase and glucanase and found a 32 $\mathrm{kcal} \mathrm{\textrm {kg } ^ { - 1 }}$ increase in metabolizable energy in diets based on corn and soybean meal.

Despite the significant difference verified between treatments for DM digestibility, there was no evidence of enzyme action increasing nutrient digestibility. However, the improvement of the ileal apparent digestibility coefficients of $\mathrm{CP}, \mathrm{MM}$, and $\mathrm{P}$ as a consequence of enzyme supplementation was clearly observed (Table 3 ).

The T2 and T3 treatments, with nutritional reductions and without enzyme supplementation, negatively affected CP digestibility. When phytase or phytase + xylanase + glucanase were introduced in $\mathrm{T} 4$ and T5, respectively, the CP in the diets was restored, reaching digestibility coefficients equivalent to those of $\mathrm{T} 1$, the control.
For the MM digestibility coefficient, although the $\mathrm{T} 4$ and $\mathrm{T} 5$ treatments did not reach means equivalent to those of the positive control, there was an increase of $16.38 \%$ for T4 versus T2 and of $10.83 \%$ for T5 versus T3. For P digestibility, there was an even greater positive effect of enzyme supplementation, leading to high levels of 70.10 and $72.48 \%$, respectively, for $\mathrm{T} 4$ and $\mathrm{T} 5$, in comparison with that of $55.93 \%$ for the control. In contrast, the digestibility of $\mathrm{Ca}$ was relatively unaffected, which could be explained by a high dietary $\mathrm{Ca}$ content. Recent data are indicative that $\mathrm{Ca}: \mathrm{P}$ ratios are critical for these kinds of results (Bavaresco et al., 2020a).

Regarding mineral deposition in chicken tibias, the positive action of the enzymes was confirmed by the responses of MM and P (Table 4). Enzymatic supplementation increased mineral content in broiler bones by $4.09 \%$ for $\mathrm{T} 4$ versus $\mathrm{T} 2$ and by $4.87 \%$ for $\mathrm{T} 5$ versus T3. The deposition of $\mathrm{P}$ in the tibias was also improved by the use of enzymes, with an increase of $4.33 \%$ for T4 versus T2 and of $7.18 \%$ for T5 versus T3. In contrast, no significant effects were observed for $\mathrm{Ca}$ and $\mathrm{Zn}$.

Dersjant-Li et al. (2015) concluded that the supplementation of broiler diets based on corn-soybean meal with 500 and 1,000 FTU kg-1 Buttiauxella phytase compensated for a reduction in nutrients (available $\mathrm{P}$, amino acids, metabolizable energy, $\mathrm{Na}$, and $\mathrm{Ca}$ ) and maintained growth performance and bone ash over a 42 day period, when compared with diets with the recommended phytase levels of 500 and $1,000 \mathrm{FTU} \mathrm{kg}^{-1}$. The experimental diets showed three $\mathrm{Ca}$ reduction levels equivalent to $0.13,0.16$, and $0.23 \%$ and to 0.16 ,

Table 4. Tibia mineral mater (MM), calcium, phosphorus, and zinc content of 28 -day-old male Cobb 500 broilers (mean \pm standard deviation) $)^{(1)}$.

\begin{tabular}{lcccc}
\hline Treatment ${ }^{(2)}$ & \multicolumn{5}{c}{ Mineral composition on a dry matter basis (\%) } \\
\cline { 2 - 5 } & MM (\%) & $\mathrm{Ca}(\%)$ & $7.02 \pm 0.39 \mathrm{ab}$ & $\mathrm{Zn}\left(\mathrm{mg} \mathrm{kg}^{-1}\right)$ \\
\hline T1 & $45.71 \pm 1.17 \mathrm{a}$ & $15.38 \pm 1.20$ & $6.64 \pm 0.47 \mathrm{ab}$ & $162.68 \pm 11.42$ \\
$\mathrm{~T} 2$ & $43.15 \pm 1.36 \mathrm{~b}$ & $14.69 \pm 1.05$ & $6.60 \pm 0.52 \mathrm{~b}$ & $161.12 \pm 12.60$ \\
$\mathrm{~T} 3$ & $43.00 \pm 1.29 \mathrm{~b}$ & $14.68 \pm 1.66$ & $6.94 \pm 0.48 \mathrm{ab}$ & $163.61 \pm 8.33$ \\
$\mathrm{~T} 4$ & $44.99 \pm 1.22 \mathrm{a}$ & $15.24 \pm 1.46$ & $7.11 \pm 0.53 \mathrm{a}$ & $167.42 \pm 9.18$ \\
$\mathrm{~T} 5$ & $45.20 \pm 1.11 \mathrm{a}$ & $15.21 \pm 1.05$ & 0.01 & $167.66 \pm 12.44$ \\
\hline Probability & $<0.0001$ & 0.44 & 0.38 \\
\hline
\end{tabular}

${ }^{(1)}$ Means followed by equal letters, in the columns, do not differ from each other by Tukey's test, at 5\% probability. ${ }^{(2)} \mathrm{T} 1$, positive control basal diet (BD) with corn and soybean meal; T2, BD with reduction of $70 \mathrm{kcal} \mathrm{kg}^{-1}, 0.16 \% \mathrm{Ca}$, and $0.15 \%$ available P; T3, BD with reduction of $100 \mathrm{kcal}^{\mathrm{kg}}{ }^{-1}, 0.16 \% \mathrm{Ca}$, and $0.15 \%$ available P; T4, T2 +500 phytase units (FTU) per kilogram; and T5, T3 $+500 \mathrm{FTU} \mathrm{kg}^{-1}+560$ xylanase units per kilogram +250 glucanase units per kilogram. 
0.19 and $0.23 \%$ in the treatments with 500 and 1,000 FTU kg ${ }^{-1}$ phytase, respectively, when compared with the positive control. The reductions in available $\mathrm{P}$ in these treatments were of 0.146 and $0.174 \%$, respectively.

The bone strength, rigidity, and flexibility of the broilers fed nutritionally reduced diets were significantly decreased (Figure 1). However, supplementation with phytase alone or combined with enzymes improved all three, indicating nutritional matrix compensation for $\mathrm{Ca}$ and available $\mathrm{P}$ content.

Strategically, the reduction of $0.16 \% \mathrm{Ca}$ and $0.15 \%$ available $\mathrm{P}$ was applied to the dietary nutritional profile, considering that phytase activity is also influenced by the contents of $\mathrm{Ca}$ and $\mathrm{P}$. Higher dietary levels of $\mathrm{Ca}$ reduce phytase activity by increasing gastrointestinal pH (Dersjant-Li et al., 2015), a condition that favors the formation of complexes between phytate and metallic cations with large ionic rays (Oh et al., 2004), with $\mathrm{Ca}^{2+}$, $\mathrm{Zn}^{2+}, \mathrm{Co}^{2+}, \mathrm{Mn}^{2+}, \mathrm{Mg}^{2+}, \mathrm{Fe}^{2+}$, and $\mathrm{Cu}^{2+}$ being the most susceptible (Kornegay, 2001). The increase in P, which is the final product of the phytase catalytic reaction, reduces the hydrolysis of phytate due to the selfregulation of the enzymatic reaction, by identifying a greater availability of the final product and decreasing the action of the enzyme (Oh et al., 2004). The dietary supplementation with $500 \mathrm{FTU} \mathrm{kg}^{-1}$ hybrid phytase was efficient for P dephosphorylation from phytate, increasing the availability of this mineral for bone deposition, besides reducing the chelating capacity of phytate.

Phytase and carbohydrate supplementation allows nutritionists to reduce energy and $\mathrm{P}$ contents in diets (Francesch \& Geraert, 2009), both known as expensive ingredients that impact production costs (Shirley \& Edwards Jr., 2003). Bavaresco et al. (2020b), using the same enzymes (500 FTU kg-1 $+560 \mathrm{TXU} \mathrm{kg}^{-1}+$ $\left.250 \mathrm{TGU} \mathrm{kg}^{-1}\right)$ and nutritional reductions (100 kcal kg-1 AMEn, $0.16 \% \mathrm{Ca}$, and $0.15 \%$ available $\mathrm{P}$ ), reported a lower production cost when chickens were fed with diets formulated with an optimized nutritional matrix with enzymatic association. Based on the present study, the combination of a hybrid phytase with specific carbohydrases (xylanase and glucanase) increases the metabolizable energy content and also the $\mathrm{CP}$ and $\mathrm{P}$ digestibility of the diets formulated with a reduction of $100 \mathrm{kcal} \mathrm{kg}^{-1}, 0.16 \% \mathrm{Ca}$, and $0.15 \%$ available $\mathrm{P}$, besides maintaining broiler bone quality by restoring mineral and $\mathrm{P}$ contents in the tibia, which results in greater bone strength, resistance, and flexibility.
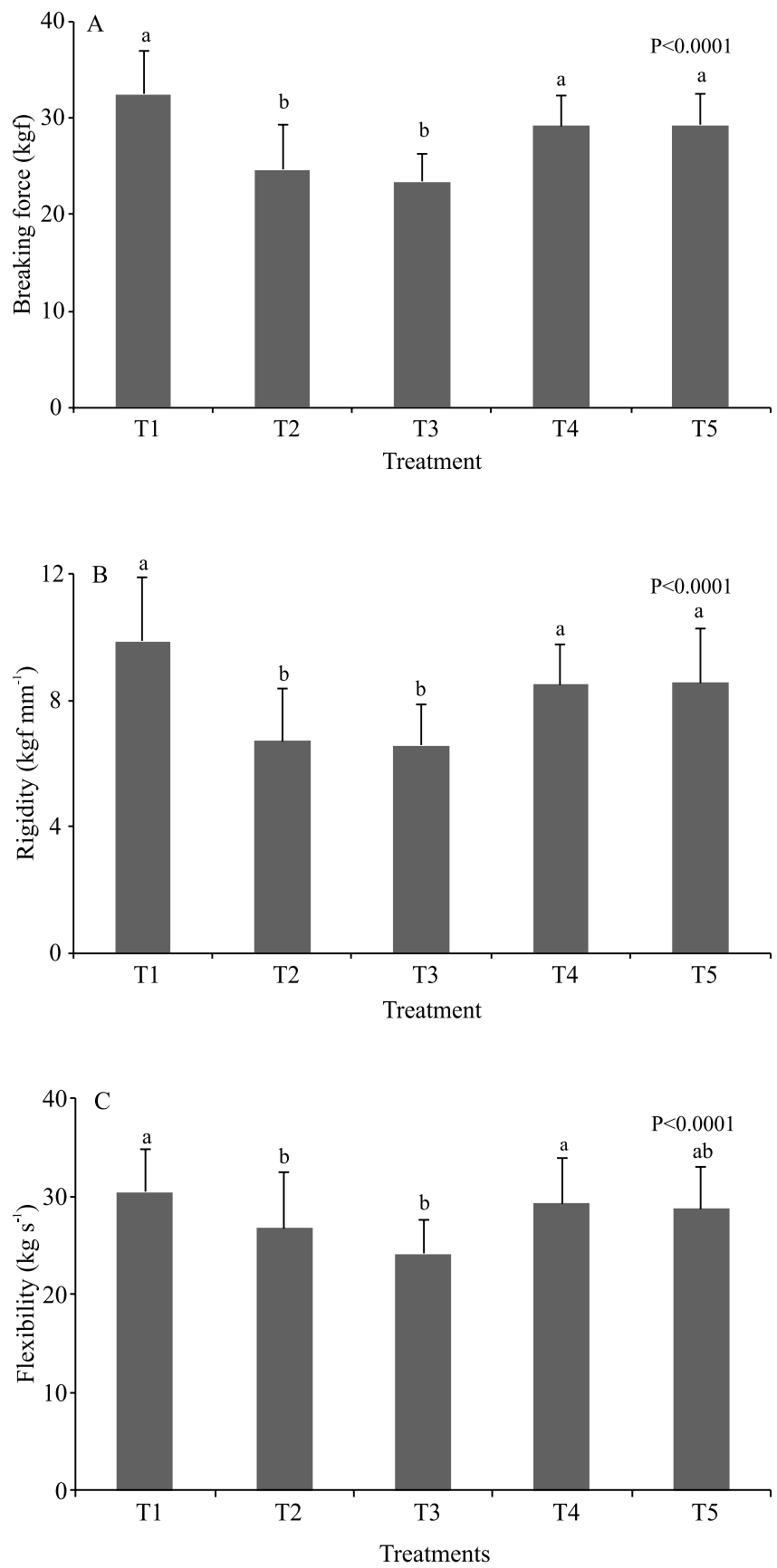

Figure 1. Tibia breaking force (A), rigidity (B), and flexibility (C) of 28-day-old male Cobb 500 broilers fed with a hybrid phytase associated with carbohydrases. Means followed by lowercase letters differ from each other by Tukey's test, at $5 \%$ probability. T1, positive control basal diet (BD) with corn and soybean meal; T2, BD with reduction of $70 \mathrm{kcal} \mathrm{kg}^{-1}, 0.16 \% \mathrm{Ca}$, and $0.15 \%$ available $\mathrm{P}$; T3, BD with reduction of $100 \mathrm{kcal} \mathrm{kg}^{-1}, 0.16 \% \mathrm{Ca}$, and $0.15 \%$ available $\mathrm{P} ; \mathrm{T} 4, \mathrm{~T} 2+500$ phytase units (FTU) per kilogram; and T5, T3 + $500 \mathrm{FTU} \mathrm{kg}^{-1}+560$ xylanase units per kilogram +250 glucanase units per kilogram. 
The experimental model was functional, confirmed by losses in nutrient digestibility and bone resistance due to the nutritional decrease used for the establishment of the experimental diets in the absence of enzyme supplementation. The addition of a $500 \mathrm{FTU} \mathrm{kg}^{-1}$ hybrid phytase, either alone or combined with carbohydrases, to poultry diets with nutritional reductions of $0.16 \% \mathrm{Ca}$, $0.15 \%$ available $\mathrm{P}$, and $70 \mathrm{kcal} \mathrm{kg}^{-1}$ metabolizable energy is effective on ileal nutrient digestibility coefficients and broiler bone quality. However, there is still the need for further studies on the synergic effect of this phytase in association with carbohydrases.

\section{Conclusions}

1. The use of 500 phytase units (FTU) per kilogram of hybrid phytase in diets with pelleted corn-soybean meal allows a good digestive performance by broilers and replaces the nitrogen-corrected apparent metabolizable energy (AMEn) at $70 \mathrm{kcal} \mathrm{kg}^{-1}$, as well as $0.16 \% \mathrm{Ca}$ and $0.15 \%$ available $\mathrm{P}$.

2. The association of $500 \mathrm{FTU} \mathrm{kg}^{-1}$ hybrid phytase and carbohydrases (560 xylanase units per kilogram + 250 glucanase units per kilogram) in diets with pelleted corn-soybean meal, when adopting an optimized nutritional matrix with $100 \mathrm{kcal} \mathrm{kg}^{-1}$ AMEn, $0.16 \%$ $\mathrm{Ca}$, and $0.15 \%$ available $\mathrm{P}$, is efficient for most studied parameters, including crude protein digestibility, phosphorus digestibility, bone mineral content, and resistance of broilers at 28 days of age.

\section{Acknowledgements}

To Coordenação de Aperfeiçoamento de Pessoal de Nível Superior (Capes), for financing, in part, this study (Finance Code 001); and to BASF S.A., for support.

\section{References}

BASF. Natuphos $\circledR_{10000}$ L: enzyme supplement for swine and poultry feeds. 2017. Available at: <https:/www.basf.com/ us/documents/en/general-business-topics/cfia-labels/pdf/ Label_982186_Natuphos_10000_L_25Jun20-CFIA.PDF>. Accessed on: Sept. 42021.

BAVARESCO, C.; KRABBE, E.; GOPINGER, E.; SANDI, A.J.; MARTINEZ, F.N.; WERNIC, B.; ROLL, V.F.B. Hybrid phytase and carbohydrases in corn and soybean meal-based diets for broiler chickens: performance and production costs. Brazilian Journal of Poultry Science, v.22, eRBCA-2019-1178, 2020 b. DOI: https://doi.org/10.1590/1806-9061-2019-1178.
BAVARESCO, C.; KRABBE, E.L.; AVILA, V.S. de; LOPES, L.S.; WERNICK, B.; MARTINEZ, F.N. Calcium: phosphorus ratios and supplemental phytases on broiler performance and bone quality. Journal of Applied Poultry Research, v.29, p.584599, 2020a. DOI: https://doi.org/10.1016/j.japr.2020.03.005.

CHOCT, M. Enzymes for the feed industry: past, present and future. World's Poultry Science Journal, v.62, p.5-16, 2006. DOI: https://doi.org/10.1079/WPS200480.

COMPÊNDIO Brasileiro de Alimentação Animal. São Paulo: Sindirações, 2009. 127p.

CUNNIFF, P. (Ed). Official Methods of Analysis of AOAC International. $16^{\text {th }}$ ed. Gaithersburg: AOAC International, 1995. Official Method 965.17.

DERSJANT-LI, Y.; AWATI, A.; SCHULZE, H.; PARTRIDGE, G. Phytase in non-ruminant animal nutrition: a critical review on phytase activities in the gastrointestinal tract and influencing factors. Journal of the Science of Food and Agriculture, v.95, p.878-896, 2015. DOI: https://doi.org/10.1002/jsfa.6998.

FRANCESCH, M.; GERAERT, P.A. Enzyme complex containing carbohydrases and phytase improves growth performance and bone mineralization of broilers fed reduced nutrient cornsoybean-based diets. Poultry Science, v.88, p.1915-1924, 2009. DOI: https://doi.org/10.3382/ps.2009-00073.

GOPINGER, E.; KRABBE, E.L.; SUREK, D.; LOPES, L.S.; AVILA, V.S. Live performance, carcass, and bone quality responses of grower and finisher broilers to dietary metabolizable energy levels. Brazilian Journal of Poultry Science, v.19, p.559566, 2017. DOI: https://doi.org/10.1590/1806-9061-2017-0508.

KORNEGAY, E.T. Digestion of phosphorus and other nutrients: the role of phytases and factors influencing their activity. In: BEDFORD, M.R.; PARTRIDGE, G.G. (Ed.). Enzymes in farm animal nutrition. Wallingford: CABI, 2001. p.237-272. DOI: https://doi.org/10.1079/9780851993935.0237.

KRABBE, E.L.; SUREK, D.; AVILA, V.S. de; RUIZ, J.H. de A.; ADER, P. Effect of dietary Natugrain TS enzyme supplementation on broiler diet digestibility. In: PSA ANNUAL MEETING, 2014, Corpus Christi. Proceedings. Champaign: Poultry Science, 2014.

LATIMER JR., G.W. (Ed.). Official methods of analysis. $19^{\text {th }}$ ed. Gaithersburg: AOAC International, 2012. Official Method 958. 01.

LEI, X.G.; WEAVER J.D.; MULLANEY, E.; ULLAH, A.H.; AZAIN, M.J. Phytase, a new life for an "old" enzyme. Annual Review of Animal Biosciences, v.1, p.283-309, 2013. DOI: https://doi.org/10.1146/annurev-animal-031412-103717.

MENG, X.; SLOMINSKI, B.A. Nutritive values of corn, soybean meal, canola meal, and peas for broiler chickens as affected by a multicarbohydrase preparation of cell wall degrading enzymes. Poultry Science, v.84, p.1242-1251, 2005. DOI: https://doi.org/10.1093/ps/84.8.1242.

NISSAR, J.; AHAD, T.; NAIK, H.R.; HUSSAIN, S.Z. A review phytic acid: as antinutrient or nutraceutical. Journal of Pharmacognosy and Phytochemistry, v.6, p.1554-1560, 2017.

OH, B.-C.; CHOI, W.-C.; PARK, S.; KIM, Y.-O.; OH, T.$\mathrm{K}$. Biochemical properties and substrate specificities of alkaline and histidine acid phytases. Applied Microbiology 
and Biotechnology, v.63, p.362-372, 2004. DOI: https://doi.org/10.1007/s00253-003-1345-0.

R CORE TEAM. R: a language and environment for statistical computing. Vienna: R Foundation for Statistical Computing, 2015.

RAVINDRAN, V. Feed enzymes: the science, practice, and metabolic realities. Journal of Applied Poultry Research, v.22, p.628-636, 2013. DOI: https://doi.org/10.3382/japr.2013-00739.

RAVINDRAN, V. Nutrition of meat animals: poultry. In: DIKEMAN, M.; DEVINE, C. (Ed.). Encyclopedia of Meat Science. $2^{\text {nd }}$ ed. Amsterdam: Elsevier, 2014. p.463-470. DOI: https://doi.org/10.1016/B978-0-12-384731-7.00024-6.

ROMERO, L.F.; SANDS, J.S.; INDRAKUMAR, S.E.; PLUMSTEAD, P.W.; DALSGAARD, S.; RAVINDRAN, V. Contribution of protein, starch, and fat to the apparent ileal digestible energy of corn- and wheat-based broiler diets in response to exogenous xylanase and amylase without or with protease. Poultry Science, v.93, p.2501-2513, 2014. DOI: https://doi.org/10.3382/ps.2013-03789.

ROSTAGNO, H.S. (Ed.). Brazilian tables for poultry and swine: composition of feedstuffs and nutritional requirements. $3^{\text {rd }}$ ed. Viçosa: UFV, 2011. 251p.

SAKOMURA, N.K.; ROSTAGNO, H.S. Métodos de pesquisa em nutrição de monogástricos. Jaboticabal: FUNEP, 2007. 283p.

SHIRLEY, R.B.; EDWARDS JR., H.M. Graded levels of phytase past industry standards improve broiler performance. Poultry Science, v.82, p.671-680, 2003. DOI: https://doi.org/10.1093/ ps/82.4.671.

SLOMINSKI, B.A. Recent advances in research on enzymes for poultry diets. Poultry Science, v.90, p.2013-2023, 2011. DOI: https://doi.org/10.3382/ps.2011-01372.
STEFANELLO, C.; VIEIRA, S.L.; CARVALHO, P.S.; SORBARA, J.O.B.; COWIESON, A.J. Energy and nutrient utilization of broiler chickens fed corn-soybean meal and cornbased diets supplemented with xylanase. Poultry Science, v.95, p.1881-1887, 2016. DOI: https://doi.org/10.3382/ps/pew070.

ŚWIĄTKIEWICZ, S.; ARCZEWSKA-WLOSEK, A. Bone quality characteristics and performance in broiler chickens fed diets supplemented with organic acids. Czech Journal Animal Science, v.57, p.193-205, 2012. DOI: https://doi.org/10.17221/6004CJAS.

TORRALlARDONA, D.; ADER, P.; COELHO, M. Validation of the extended matrix values for energy and amino acids of a new novel 6-phytase, Natuphos E, in weaned piglets. Journal of Animal Science, v.95, p.117-118, 2017. DOI: https://doi.org/10.2527/asasmw.2017.244.

WOYENGO, T.A.; NYACHOTI, C.M. Review: supplementation of phytase and carbohydrases to diets for poultry. Canadian Journal of Animal Science, v.91, p.177-192, 2011. DOI: https://doi.org/10.4141/cjas10081.

YU, B.; CHUNG, T.K. Effects of multiple-enzyme mixtures on growth performance of broilers fed corn-soybean meal diets. Journal of Applied Poultry Research, v.13, p.178-182, 2004. DOI: https://doi.org/10.1093/japr/13.2.178.

ZARGHI, H. Application of Xylanas and $\beta$-Glucanase to Improve Nutrient Utilization in Poultry Fed Cereal Base Diets: Used of Enzymes in Poultry Diet. Insights Enzyme Research, v.2, p.1-7, 2018. DOI: https://doi.org/10.21767/2573-4466.100011.

ZENEBON, O.; PASCUET, N.S.; TIGLEA, P. (Coord.). Métodos físico-químicos para análise de alimentos. 4.ed., 1.ed. digital. São Paulo: Instituto Adolfo Lutz, 2008. 1020p. 